Etikonomi

Volume 16 (1), April 2017

P-ISSN: 1412-8969; E-ISSN: 2461-0771

Page $1-12$

\title{
DETERMINANTS OF FINANCIAL PERFORMANCE IN THE INDONESIAN ISLAMIC INSURANCE INDUSTRY
}

\author{
Iman Pirman Hidayat, Irman Firmansyah \\ Universitas Siliwangi \\ imanfirman@unsil.ac.id,irman_tasik@yahoo.co.id
}

\begin{abstract}
.
The purpose of this study is to determine the role of the board of directors as an operating executive, as the company's supervisory board of commissioners, the proportion of managerial ownership and institutional ownership as well as leverage on the financial performance of Islamic insurance industry. The method used is multiple regression analysis and Moderated Regression Analysis. Data of company successfully researched as many as 15 Islamic insurance companies in Indonesia with a study period of 2011 to 2015. The results showed that the board does not affect the financial performance of Islamic insurance industry. The variables such as: commissioners, managerial ownership, and institutional ownership and leverage positive effect on the financial performance of Islamic insurance industry in Indonesia. The size of the company weakens the relationship between the number of directors and leverage to financial performance, and did not moderate the relationship between the number of commissioners, managerial ownership and institutional ownership of the financial performance of Islamic insurance industry in Indonesia.
\end{abstract}

Keywords: good corporate governance, leverage, financial performance, Islamic insurance

\begin{abstract}
Abstrak.
Tujuan dari penelitian ini yaitu untuk mengetahui peran dewan direksi sebagai pelaksana operasional, dewan komisaris sebagai pengawas perusabaan, proporsi kepemilikan manajerial dan kepemilikan institusional serta leverage terbadap kinerja kenangan perusabaan asuransi syariah. Metode yang digunakan yaitu analisis regresi berganda dan analisis regresi moderasi. Data perusabaan yang berhasil diteliti yaitu sebanyak 15 perusahaan asuransi syariah di Indonesia dengan periode penelitian tabun 2011 sampai 2015. Hasil penelitian menunjukean bahwa dewan direksi tidak berpengarub terhadap kinerja keuangan asuransi syariah. Dewan komisaris, kepemilikan manajerial, kepemilikean institusional dan leverage berpengaruh positif terhadap kinerja kenangan asuransi syariah di Indonesia. Sedangkan ukuran perusahaan memperlemah bubungan antara jumlah direksi dan leverage dengan kinerja keuangan, dan tidak memoderasi bubungan antara jumlah dewan komisaris, kepemilikan manajerial dan kepemilikan institusional terbadap kinerja keuangan asuransi syariah di Indonesia.
\end{abstract}

Kata Kunci: tata kelola perusahaan baik, leverage, kinerja keuangan, asuransi syariah

Received: January 17, 2017; Revised: February 10, 2017; Approved: March 10, 2017 
The Impact of Good Corporate Governance

Iman Pirman Hidayat, Irman Firmansyah

\section{INTRODUCTION}

Currently the insurance industries in Indonesia are rising rapidly. It is increasingly clear that people are starting to understand the insurance is part of risk management to be prepared in life either as self-protection, businesses and others. With a total population of Indonesia The ASEAN and number four world and has a number of SME business is very large about 58 million units and continues to grow each year. This growth supported by agricultural land and farms stretching from Sabang to Merauke, into opportunities greatly to the growth of insurance companies in Indonesia because of protection regarding property owned community is needed to avoid the risk.

Not only conventional insurance companies, there is also the insurance sector with respect to the advancement of understanding sharia society on sharia economy. At the end of 2014, there are 49 Islamic insurance companies in Indonesia of 5 types of companies. Until now, the growth of Islamic insurance companies continues to grow.

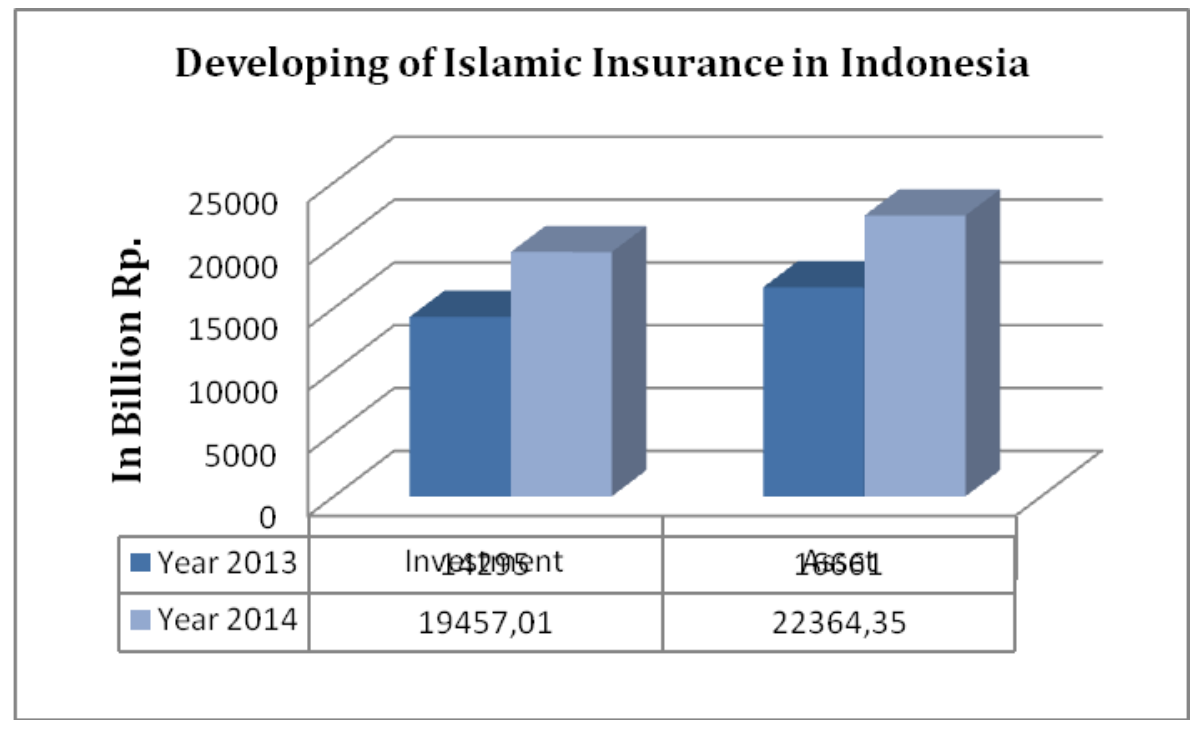

Figure 1. Developing of Islamic Insurance in Indonesia

Based on the Figure 1, it can be seen that the investments and assets of Islamic insurance company in Indonesia has increased from 2013 to 2014. This increase is of course to be a positive impact on the company's performance because the larger the assets will give a burden to the company if the source of wealth cannot be put to good use. Thus research is needed regarding the performance of Islamic insurance company as a proxy of success in obtaining profit. To assess the financial performance of companies can use Return on Assets (ROA). ROA focus the company's ability to earn profits seen from its assets. 
More than that, other things more important is not the high financial performance that has been made at this time but what factors are causing the rise and fall of financial performance. This is because if the company does not know what are the factors that lead to increased financial performance so that if one day the financial performance is down, then the management did not know which factors cause a decline in the financial performance. Therefore, considering the Islamic insurance companies in Indonesia are increasing, it is very urgent to do research on the factors that lead to high and low of the financial performance of Islamic insurance company in Indonesia that the rising trend in the company's assets can be maintained.

Among of factors that predicted affect the financial performance that is mechanisms of good corporate governance (GCG), which is based on several studies that have been done before. This is because good corporate governance (GCG) basically has the objective to provide advances to the company performance. Corporate governance is more inclined to a set pattern of corporate behavior is measured through performance, growth, financing structures, and the treatment of shareholders and stakeholders. So it can serve as the basis for analysis in assessing corporate governance in a country to meet transparency and accountability in a systematic decision-making that can be used as the basis for a more accurate measurement of the company performance. In conducting its operations, corporate governance mechanism can be seen from several indicators: number of board of directors, number of commissioners, managerial ownership and institutional ownership.

Some research results relating to the effect on GCG implementation to the performance. Klapper and Love (2002) found a positive relationship between corporate governance and corporate performance as measured by Return on Assets (ROA). Likewise Nuswandari (2009) examined the Corporate Governance Perception Index of corporate performance in companies listed on the BEI in 2001 and 2005. The results of the regression model analysis showed that the CGPI positive significantly effect on operating performance. Windah and Andono (2013) showed that GCG has no effect on the financial performance.

GCG addition, other factors suspected to affect the company's financial performance is leverage. Leverage is the ratio between debts with own capital. This ratio is used to determine the amount of funds provided by the creditor to the owner of the company so that this ratio is used to determine every penny of their own capital as 
The Impact of Good Corporate Governance .........

Iman Pirman Hidayat, Irman Firmansyah

collateral debt. This ratio is described by the debt-to-equity ratio (DER) i.e. the higher this ratio indicates the higher risk of failure that may occur in the company, and vice versa when the lower this ratio, the show also lower the risk of failure that may occur in the company. So it will have an impact on the bank's financial performance.

The research result Stein (2012) states that DER negatively significant effect on profitability. While research Usman (2003) and Tobing (2006) stated that the leverage ratio positive effect on the level of profitability. Besides the two above factors affecting the company's financial performance, other factors must be considered, namely the size of the company in order to distinguish characteristics in predicting the company's financial performance. Businesses are usually more flexible in obtaining financial performance compared with small companies. But this has to be proved by a research, especially on Islamic insurance company that is currently being developed in Indonesia.

Therefore, based on exposure and some results of the study above, the authors aim to investigate the influence of the Good Corporate Governance mechanism (amount of directors, amount of commissioners, managerial ownership and institutional ownership) and leverage toward performance of Islamic insurance company with the size of the company as a moderating variable. So this research is important because it will be a new finding for the Islamic insurance, especially as a model in order to increasing the financial performance of companies which exist at the stage of business growth. Much can be done by the management in improving financial performance and one of them through the research. This study provides an overview for companies that are growing by inserting variable size companies to determine the effect of company size on the relationship between the variables that affect financial performance.

\section{METHOD}

This study used a population insurance companies sharia sector in Indonesia from 2011 to 2014. Of the total population used purposive sampling method to select samples that will be used in this study. Population is taken during that period because limited of researchers in obtaining data. Islamic insurance company that the research sample as many as 15 companies comprising of ACA Sharia Unit, Adira Sharia Unit, Askrida Sharia, Bringinlife Sharia, Mega Sharia, Manulife Sharia, Tokio Marine Sharia Unit, National Re Sharia Unit, CAR Sharia, Allianz Sharia, Bumiputera Sharia, Sinarmas Sharia, Panin Sharia, Sunlife Sharia and Astralife Sharia. 
This research is using regression analysis to answer the research problem. Regression analysis is the study of the dependence of the dependent variable with one or more independent variables to predict the value of the population average or the average value of the dependent variable based on the value of the independent variables are known. This analysis is used because it can directly conclude independent variables used either partially or simultaneously. Regression analysis result is regression coefficients for each independent variable. This coefficient is obtained by predicting the value of the dependent variable in an equation. In regression analysis of moderating regression analysis (MRA), in addition to measuring the strength of the relationship between two or more variables, also shows the direction of the relationship between the independent and dependent variable.

The basic model can be formulated as follows:

$\mathrm{ROA}=\mathrm{a}+\beta 1 \mathrm{DIR}+\beta 2 \mathrm{COM}+\beta 3 \mathrm{MAN}+\beta 4 \mathrm{INS}+\beta 5 \mathrm{LEV}+\mathrm{e}$

$\mathrm{ROA}=\mathrm{a}+\beta 1 \mathrm{DIR}+\beta 2 \mathrm{COM}+\beta 3 \mathrm{MAN}+\beta 4 \mathrm{INS}+\beta 5 \mathrm{LEV}+\beta 6 \mathrm{SIZE}+\beta 7$ (DIR $* \mathrm{SIZE})+\beta 8(\mathrm{COM} * \mathrm{SIZE})+\beta 9(\mathrm{MAN} * \mathrm{SIZE})+\beta 10(\mathrm{INS} * \mathrm{SIZE})+\mathrm{e}$

Where:

ROA: Return on Assets, DIR: Amount of Directors, COM: Amount of Commissioners, MAN: percentage of managerial ownership, INS: the percentage of institutional ownership, LEV: leverage, SIZE: company size.

\section{RESULT AND DISCUSSION}

Based on research data obtained from Islamic insurance company in Indonesia during the study period from 2011 until 2015, it obtained 15 Sharia Insurance Company in accordance with the required data. Before the OLS analysis, it first has performed classical assumption to see the quality of the data to ensure data is worthy of analysis. Classic assumption test consists of normality test, multicollinearity test, and heteroscedasticity test. The results of the processing of data quality by using SPSS ver. 20 are presented in Table 1.

A good regression model is that has a normal distribution or near-normal which is intended to test whether the independent variable and the dependent variable in the regression model has a normal distribution or not. Test of normal distribution is conducted by the Kolmogorov-Smirnov test. Based on table 1, we can see the value Asymp. Sig (2tailed) is 0.606 . This value is greater than 0.05 or $5 \%$. So it concluded that the data is expressed in normal distribution and it can be said that the regression model to meet the assumptions of normality so that data is fit for use. 
The Impact of Good Corporate Governance .........

Iman Pirman Hidayat, Irman Firmansyah

Table 1. Classical Assumption Test

\begin{tabular}{llllll}
\hline \multicolumn{2}{l}{ Classic Assumption Test } & & & \\
\hline $\begin{array}{l}\text { Kolmogorov- } \\
\text { Smirnov Test }\end{array}$ & $\begin{array}{l}\text { Asymp. Sig. (2- } \\
\text { tailed) }\end{array}$ & & & 0,606 & \\
\hline Glejser Test & Sig. COM & & & 0,585 & \\
& DIR & & & 0,981 & \\
& MAN & & \multicolumn{2}{c}{0,930} & \\
& INS & & \multicolumn{2}{c}{0,126} & 0,091 \\
\hline & DER & & \multicolumn{3}{c}{} \\
\hline Collinearity & & VIF. COM & 1,194 & TOL. COM & 0,838 \\
Statistics & DIR & 1,419 & DIR & 0,705 \\
& & MAN & 1,641 & MAN & 0,609 \\
& & INS & 2,538 & INS & 0,394 \\
& & DER & 2,232 & DER & 0,448 \\
& & SIZE & 2,897 & SIZE & 0,345 \\
\hline
\end{tabular}

Source: Output SPSS, (data processed)

The second data quality testing is multicollinearity test. In Table 1 it can be seen that the VIF value of each independent variable on Islamic insurance company in Indonesia to be around the numbers 1 (less than the 10). From these results it can be seen that in the regression model free of multicollinearity between independent variables. The next test of the quality of data that heteroscedasticity test. To detect the heteroscedasticity then used Glejser Test. From Table 1 it can be seen that the sig. all independent variables more than 0.05 . This shows that no heteroscedasticity in regression models in this study. After testing the data quality is complete, then performed a regression is analysed. Analysis of the data used in this research is the analysis of panel data models Ordinary Least Square (OLS).

From Table 2, it can be made the regression equation is as follows:

$$
\begin{aligned}
\mathrm{Y}= & -2,771+0,058 \mathrm{DIR}+0,003 \mathrm{COM}+0,631 \mathrm{MAN}+0,413 \mathrm{INS}-0,022 \mathrm{LEV} \\
& +0,185 \mathrm{SIZE}+\mathrm{e}
\end{aligned}
$$

Based on the analysis in Table 2 obtained significance value variable board of directors that is 0.826 with a positive coefficient, thus the amount of board of directors does not affect on financial performance of the Islamic Insurance Company in Indonesia. Furthermore, the significant value of variable commissioners is 0,001 with a positive coefficient, or by looking at the t-value of 3.519 which is greater than t table (2.000) the number of commissioners significant positive effect on financial performance of Islamic Insurance Company in Indonesia. Furthermore, the significant value of managerial ownership variable that is 0,002 with a positive coefficient, or by looking at the $t$ value of 3.152 which is greater than t-table (2.000) then the composition of managerial ownership 
has positive effect on financial performance of Islamic Insurance Company in Indonesia. Furthermore, the significant value of institutional ownership variable is 0.000 with a positive coefficient, then the composition of institutional ownership positively effect on financial performance Islamic Insurance Company in Indonesia. Recently variable leverage the significant value that is 0,014 with a negative coefficient, or by looking at the $t$ value of -2.522 then leverage negatively affect on financial performance Islamic Insurance Company in Indonesia.

Table 2. Result of $t$ Test

\begin{tabular}{|c|c|c|c|c|c|c|}
\hline \multirow[b]{2}{*}{ Mod } & & \multicolumn{2}{|c|}{ Unstandardized Coefficients } & $\begin{array}{l}\text { Standardized } \\
\text { Coefficients }\end{array}$ & \multirow[b]{2}{*}{$\mathrm{t}$} & \multirow[b]{2}{*}{ Sig. } \\
\hline & & $\mathrm{B}$ & Std. Error & Beta & & \\
\hline \multirow[t]{7}{*}{1} & (Constant) & -2.771 & .403 & & -6.876 & .000 \\
\hline & DIR & .003 & .012 & .024 & .220 & .826 \\
\hline & $\mathrm{COM}$ & .058 & .017 & .345 & 3.519 & .001 \\
\hline & MAN & .631 & .200 & .363 & 3.152 & .002 \\
\hline & INS & .413 & .090 & .658 & 4.602 & .000 \\
\hline & DER & -.022 & .009 & -.338 & -2.522 & .014 \\
\hline & SIZE & .185 & .028 & 1.008 & 6.592 & .000 \\
\hline
\end{tabular}

Source: Output SPSS, (data processed)

After knowing the factors that affect the financial performance of Islamic Insurance, then further analyzed whether the company size can also moderate the relationship between the independent and dependent variables. In this analysis, adding moderating variables (size) by multiplying the moderating variable and independent variables. The results of the research as well as data processing that has been done found some different findings with the results of previous studies. This happens because of the scope of current research conducted in the different type with previous studies that a differentiator with empirical studies.

Regarding the effect of board of directors on the financial performance resulted in that the board of director does not affect to financial performance of Islamic insurance company in Indonesia. This contrasts with research Faisal (2005) states that the board of directors is positively relationship with firm performance. This means that the greater amount of board of directors then not provide significant benefits for the Islamic insurance company because of the measures taken would be even slower. The important decision that must be made by the board of directors was not due to the large amount of boards of directors. While the amount of directors is not the benchmark the quality of decisions taken, the decision for each individual director who is qualified and able to solve all existing 
The Impact of Good Corporate Governance .........

Iman Pirman Hidayat, Irman Firmansyah

problem. Therefore election's board should be supported with good human resources to be able to provide a great benefit to the company for Islamic insurance companies are in the developing stages and so we need people who are qualified.

Table 3. Output Analysis MRA

\begin{tabular}{llrrrr}
\hline \multicolumn{7}{c}{ Unstandardized Coefficients } & \multicolumn{2}{c}{ Standardized } \\
Coefficients & & \\
\hline 1 (Constant) & \multicolumn{1}{c}{ B } & \multicolumn{1}{c}{ Std. Error } & \multicolumn{1}{c}{ Beta } & \multicolumn{1}{c}{ t } & \multicolumn{1}{c}{ Sig. } \\
\hline COM & -3.664 & 4.132 & & -.887 & .379 \\
DIR & .551 & .343 & 3.256 & 1.608 & .113 \\
MAN & .304 & .172 & 2.655 & 1.763 & .083 \\
INS & 6.536 & 6.695 & 3.757 & .976 & .333 \\
DER & -1.879 & 3.870 & -2.993 & -.485 & .629 \\
SIZE & .564 & .152 & 8.744 & 3.706 & .000 \\
SIZE_COM & .298 & .312 & 1.624 & .955 & .343 \\
SIZE_DIR & -.042 & .029 & -3.057 & -1.461 & .149 \\
SIZE_MAN & -.025 & .014 & -2.958 & -1.733 & .088 \\
SIZE_INS & -.570 & .527 & -3.904 & -1.081 & .284 \\
SIZE_DER & .149 & .287 & 2.856 & .520 & .605 \\
\hline
\end{tabular}

Source: Output SPSS, (data procesed)

As with the amount of board of commissioners, this study has shown that the amount of the board of commissioners positive effect on financial performance. So this research is consisting with Chtourou et al (2001), which explained that the amount of the board greater than the mechanism of monitoring the company's management, the better. Thus the Islamic insurance company that is currently expanding needs a lot of scrutiny because it is still very vulnerable to other competitors. Most Islamic insurance company in Indonesia is shaped so that the sharia unit of capital quite a bit. Therefore, the existing capital should be utilized through a very good supervision. The greater number of commissioners will provide great benefits for the company's progress and on the basis of this study indicate that the company is not in vain spend some costs for the sake of the implementation of the company's operating properly. Higher performance proves that the commissioners have been working in accordance with his duties.

The results of this study found that managerial ownership has positive affect on the financial performance. Consist with the research by Wedari (2004), found that insider ownership positive and significant effect on the performance of companies and contrary to research Hermalin and Weisbach (2003) showed that the higher the percentage of managerial ownership will lowering quality of financial statements and to impact the 
declining company's performance. Through this research we can find that is not the managerial ownership can decrease financial performance but to be seen what kind of conditions the company. If the company is in the form of business units, the managerial ownership becomes an important factor because it will have high contribute to improve financial performance. Managerial ownership, which shows that management, co-owns the company's shares have managed to increase the performance of the company. Management is still working with high professionalism because on the other hand, it will provide benefits both corporate and individual in the future. Responsibilities are related to the corporation, the management of the capital will work with the maximum because they do not want to bear the risk that would later befall you as an owner of capital.

Furthermore, the influence of institutional ownership shows that institutional ownership positively affects to financial performance. This is contrary to Faisal (2005) also found that institutional ownership has not been effective to monitoring management in increasing corporate performance. Faisal turns research results can be disproved by the results of this study. Proved that the Islamic insurance company that the owner of the institution has been able to give a good effect on the improvement of financial performance. This happens because the institution has the capital on Islamic insurance company has a great responsibility to make a profit from their investment. So it will strive to provide inputs for the company as evidence of the seriousness in investing. If the company's losses, institutions shall also bear the loss and will certainly beyond the expectations of the investment embedded. The results show that institutional ownership is good for the company's performance.

The findings further that the effect of leverage as measured by debt to equity ratio (DER), which indicates that the leverage negatively affect to financial performance. The results are consistent with research Campbell (2002), Miyajima, et.al (2003) and Stein (2012) showed that DER negative effect on ROA. This happens because the larger ratio DER then the greater the amount of debts owed that to restore debt burden accompanied by a load on the interest / profit-sharing loans will burden the company emerging as the Islamic insurance company in Indonesia which is currently being developed. It is not allowed to have debt, but cash inflows derived from the debt should be used as well as better to meet the operational needs of companies such costs should be held. Even more, in the longterm debt held must be able to provide a great benefit to the company's profit will be 
The Impact of Good Corporate Governance .........

Iman Pirman Hidayat, Irman Firmansyah

obtained one of which comes from debts owed. But this need a very concrete calculation given the current Islamic insurance company is still in the developing stages.

In addition to the findings above, this study also analyzes about whether the company size was able to strengthen or weaken the relationship between the independent variable on the dependent variable. The results of this study indicate that the company size is only able to weaken the relationship between the amount of board of director and leverage with financial performance. This means that the larger the company, the board of directors does not need too much because it will slow down the decision-making management. Usually too many directors will slow down the work because too many considerations and vested interests inherent in each of the directors. Therefore, the strategies that can be taken if the larger companies are maximizing the functionality of directors not add to the amount. Although few in number, but work with the maximum.

Meanwhile, related to the leverage, the greater the company size, no longer need to have a leverage ratio which is great because if the company was great, the company is stable so that the loan from the outside can be reduced. Financial stability in the Islamic insurance companies the same as in other types of companies that the larger the company the more stable finances. Besides that factor, Rahmawati (2017) also found that return on equity, debt on asset ratio, and net profit margin had an impact on Islamic insurance stock return.

\section{CONCLUSION}

Based on the research and discussion above, this research can be summarized as follows: (1) The board of directors does not affect the financial performance of Islamic insurance companies in Indonesia. (2) The Board of Commissioners positive effect on the financial performance of Islamic insurance companies in Indonesia. (3) Managerial Ownership positive effect on the financial performance of Islamic insurance companies in Indonesia. (4) Institutional Ownership positive effect on the financial performance of Islamic insurance companies in Indonesia. (5) Leverage negatively affect the financial performance of Islamic insurance companies in Indonesia. (6) Size weaken the relationship between the amount of the board of directors and the leverage of the financial performance of Islamic insurance company in Indonesia, as well as not moderate the relationship between the board of commissioners, managerial ownership and institutional ownership on the financial performance. 


\section{REFERENCES}

Campbell, K. (2002). Ownership Structure and The Operating Performance of Hungarian Firms. Working Discussion Paper.University of Stirling.

Faisal. (2005). Analisis Agency Cost, Struktur Kepemilikan dan Mekanisme Corporate Governance (Analysys of Agency Cost, Ownership Structure, and Corporate Governance Mechanism). Jurnal Riset Akuntansi Indonesia, Vol 8 (2): 175-190.

Hermalin, B. E. \& M.S. Weisbach. (2003). Boards of Directors as an Endogenously Determined Institution: A Survey of the Economic Literature. Economic Policy Review. April 2003. FRBNY

Kalpper, L.F. \& I. Love. (2002). Corporate Governance, Investor Protection, and Performance in Emerging Markets. Policy Research Working Paper, No. 2818. Washington DC: World Banks

Miyajima, H., Y. Omi, \& N. Saito. (2003). Corporate Governance and Performance in Twentieth-Century Japan. Business and Economic History. Vol. 1: 1-36.

Nuswandari, C. (2009). Pengaruh Corporate Governance Perception Index Terhadap Kinerja Perusahaan Pada Perusahaan Yang Terdaftar di Bursa Efek Jakarta (The Influence of Governance Perception Index to Company's Performance in The Companies Listed in Jakarta Stock Exchange). Jurnal Bisnis dan Ekonomi. Vol. 16 (2): 70-84.

Rahmawati, A. (2017). Kinerja Keuangan dan Tingkat Pengembalian Saham: Studi Pada Perusahaan Asuransi di Bursa Efek Indonesia (Financial Performance and Stock Return: Study at Insurance Companies Listed in The Indonesian Stock Exchange). Esensi: Jurnal Bisnis dan Manajemen. Vol. 7 (1): 1-14.

Stein, E.T. (2012). Pengaruh Struktur Modal (Debt Equity Ratio) Terhadap Profitabilitas (Return On Equity) (The Effect of Capital Structure (Debt Equity Ratio) on Profitability (Return on Equity). (Unpublished Bachelor Thesis). Makassar: Universitas Hasanuddin.

Tobing, T. S. M. (2006). Pengaruh Struktur Modal Terhadap Profitabilitas Pada Industri Makanan dan Minuman Yang Tercatat di Bursa Efek Jakarta (The Influence of Capital Structure to Profitability in Food and Beverage Companies Listed in Jakarta Stock Exchange). (Unpublished Bachelor Thesis). Medan: Universitas Sumatera Utara. 
Usman, B. (2003). Analisis Rasio Keuangan dalam Memprediksi Perubahan Laba pada Bank-Bank di Indonesia (Analysis of Financial Ratio in Predicting the Bank's Profit Changes in Indonesia). Media Riset Bisnis \& Manajemen, Vol. 3, No. 1: 59-74.

Wedari, L.K. (2004). Analisis Pengaruh Proporsi Dewan Komisaris dan Keberadaan Komite Audit Terhadap Aktivitas Manajemen Laba (The Analysis of Effect Commisioner Board Proportion and Audit Commitee to Earning Management). Simposium Nasional Akuntansi VII, Denpasar Bali

Windah, G. C. \& F.A. Andono. (2013). Pengaruh Penerapan Good Corporate Governance terhadap Kinerja Keuangan Perusahaan Hasil Survey The Indonesian Institute Perception Governance (IICG) Periode 2008-2011 (The Effect of Good Corporate Governance on Financial Performance in Companies Listed in The Indonesian Institute Perception Governance (IICG) Period 2008-2011). Calyptra: Jurnal Ilmiah Mahasiswa Universitas Surabaya, Vol. 2, No. 1: 1-20

Winata, F. (2014). Pengaruh Corporate Governance terhadap Tax Avoidance Pada Perusahaan yang Terdaftar di Bursa Efek Indonesia tahun 2013. Tax \& Accounting Review, Vol. 4 (1): 71-80. 